UDC $504.062+528.8$

Oleksandr S. Greben ${ }^{1}$, Principal researcher

e-mail: $\underline{\text { a.greben@khai.edu }}$

Oleksandr M. Trofymchuk ${ }^{2}$, Corresponding member of NASU, D. S. (Technical), Professor, Director of the Institute

ORCID ID 0000-0003-3782-4209 e-mail: itelua@ kv.ukrtel.net

${ }^{1}$ National Aerospace University «Kharkiv Aviation Institute», Kharkiv, Ukraine

${ }^{2}$ Institute of Telecommunication and Global Information Space of NASU, Kyiv, Ukraine

\title{
FEATURES OF RESERVOIRS EUTROFICATION BY ELEMENTS OF AGROCHEMICAL FERTILIZERS
}

\begin{abstract}
Phosphorus, also as nitrogen and potassium, is essential for the normal development of plants. The source of phosphorus for plants is phosphate of soil, mainly calcium phosphate $\mathrm{Ca}_{3}\left(\mathrm{PO}_{4}\right)_{2}$. But for most soils, calcium phosphate is not enough. In addition, due to its insolubility in the water, it is practically inaccessible for plants. Therefore, the application of soluble phosphates, the so-called phosphate fertilizers, into soil, is extremely important for increasing agricultural yields.

The article analyzes the chemical composition of agrarian fertilizers, and mechanisms of their elements influence on the processes of aquatic ecosystems life. Their solubility in the water is analyzed, as well as their probabilistic influence on the development of flowering and reservoirs silting processes, reduction of their inhabitant's species populations.
\end{abstract}

Keywords: remote sensing; geoinformation system; agricultural; eutrophication; ecology

\section{Introduction}

The processes of reservoirs eutrophication are the processes of contaminated waste water reset, washing out and weathering of specific substances from soils, washing out of organic and inorganic fertilizers from agricultural land surfaces, washing out of manure from farms, subsidence contaminations from the atmosphere (Fig. 1).
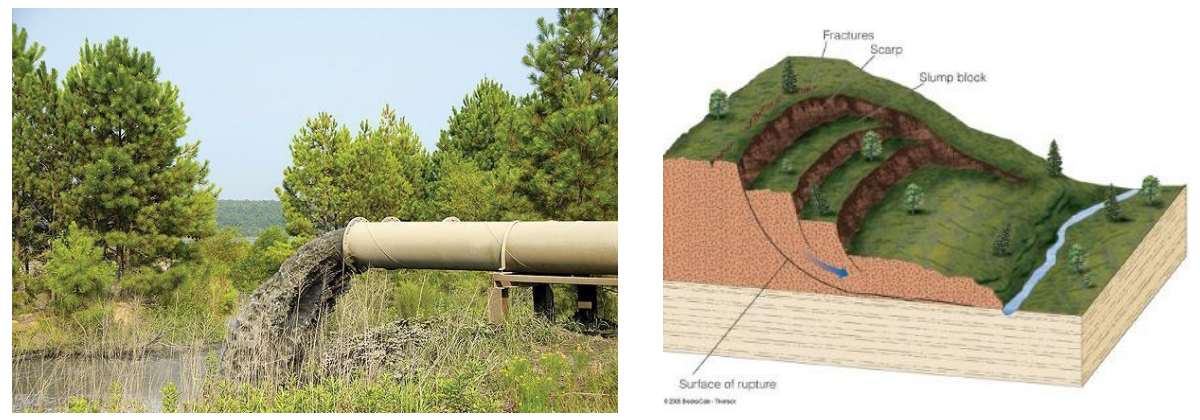

Fig. 1 - Examples of surface runoff pollution ways

The course of the eutrophication process takes place in several successive stages. At the first stage there is an accumulation of nitrogen or phosphorus minerals in the 
water. This process is usually not long-lasting. In the future there is an intensive algae growth. As a result, phytoplankton biomass, water turbidity and oxygen concentration in the upper layers of the water are increased.

One of the aquatic ecosystem's eutrophication consequences is an increase of blue-green algae growth intensity, which significantly reduces the indicators of water availability for drinking (bad smell and taste), for recreational purposes (swimming, bathing, fishing). Such water is allergenic and toxic. Metabolites of blue-green algae are sources of many diseases among fish and warm-blooded animals.

The next step is oxygen complete disappearance in the water object depths. After that, the processes of anaerobic fermentation begin [1].

Algae begin to die and gradually disappear, there are processes of bottom sludge intensive sedimentation. In the structure of these sludges, there is a high content of organic matter. Due to such processes occurrence, there are changes in the zoocenosis.

The development of blue-green algae (see Figure 2) is also a significant negative factor for the existence of aquatic ecosystems zoological diversity. Zooplankton is a natural filtrate, which usually absorbs small algae, and when the processes of reservoirs "flowering" occur, the colonial forms, which are practically not absorbed by zooplankton, are developing, on the contrary. They become members of the trophic chain only after interacting with destroying them bacteria. The diversity of zooplankton in the direction of community simplification diminishes. Small species begin to prevail, but they are not able to destroy organic matter with the same intensity.
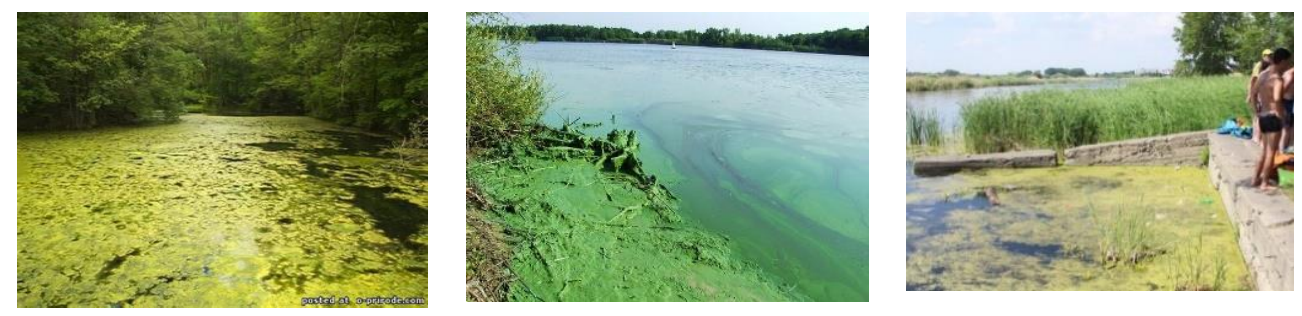

Fig. 2 - Examples of blue-green algae excessive growth

After the blue-green algae death toxins of particular importance are formed because they have a wide range of biological effects and affect the central nervous system of animals and people [2].

A separate contamination factor for water ecosystems is the washing out of manure from farms and fields (for example, their concentration is approximately 100 times higher than the rates of wastewater cleaned by treatment facilities).

\section{Main part}

The pollution of reservoirs is judged by the change in their properties and composition under the influence of direct or indirect human activity and as a result of such activity became unsuitable for at least one type of water usage (see Table 1). The deterioration of water quality indicators due to changes in its organoleptic properties and the appearance of harmful substances is a direct criterion of aquatic ecosystems pollution. 
A special role is played by microorganisms (or bacteria) because they may change to adapt and transform previously unknown organic compounds. Such compounds are synthesized today and as a result of their use in the process of human life, they enter the reservoirs, infecting not only the hydrosphere, but also living organisms.

Table 1 - Classes of natural water quality depending on Water Pollution Index values

\begin{tabular}{|l|c|c|}
\hline Water contamination level & Value of WPI & Water quality classes \\
\hline Very Clean & Up to 0.2 & 1 \\
\hline Pure & $0.2-1.0$ & 2 \\
\hline Moderately dirty & $1.1-2.0$ & 3 \\
\hline Contaminated & $2.1-4.0$ & 4 \\
\hline Dirty & $4.1-6.0$ & 5 \\
\hline Very dirty & $6.1-10.0$ & 6 \\
\hline Extremely dirty & $>10.0$ & 7 \\
\hline
\end{tabular}

Let's consider the water ecosystems pollution aspects as a result of agricultural activity. Usually the main factors of eutrophication are phosphorus and nitrogen compounds in the form of phosphates and nitrates.

In the territories of test sites according to the data of the land user in 2018 the following fertilizers were added (Table 2).

Table 2 - Characteristics of used fertilizers

\begin{tabular}{|c|c|c|l|c|}
\hline Formula & $\begin{array}{c}\text { Cultivated } \\
\text { culture }\end{array}$ & $\begin{array}{c}\text { Rate of drug } \\
\text { expenditure }\end{array}$ & $\begin{array}{c}\text { Active substance } \\
\text { concentration }\end{array}$ & $\begin{array}{c}\text { Preparation } \\
\text { form }\end{array}$ \\
\hline NPK-15 & $\begin{array}{c}\text { Crops } \\
\text { spinal cord }\end{array}$ & $150-350 \mathrm{~kg} / \mathrm{ha}$ & $\begin{array}{l}\mathrm{N}-15 \%, \\
\mathrm{P}_{2} \mathrm{O}_{5}-15 \%, \\
\mathrm{~K}_{2} \mathrm{O}-15 \%, \\
\mathrm{~S}-10 \%\end{array}$ & Granules \\
\hline & Corn & $\begin{array}{c}20 \mathrm{~kg} / \mathrm{ha}-\mathrm{with} \\
\text { foliar feeding; }\end{array}$ & $\begin{array}{l}\left(\mathrm{NH}_{2}\right)_{2} \mathrm{CO}, \\
\text { permissible } \\
\text { concentration of } \\
\text { solution for foliar } \\
\text { feeding } 5-15 \%\end{array}$ & $\begin{array}{c}\text { Amide fertilizer, } \\
\text { water soluble }\end{array}$ \\
& Pea & $\begin{array}{c}200 \mathrm{~kg} / \mathrm{ha} \text { for } \\
\text { sowing }\end{array}$ & $\begin{array}{l}\mathrm{N}-16 \%, \\
\mathrm{~K}-16 \%,\end{array}$ & Granules \\
\hline NPK-16 & $\begin{array}{c}\text { Crops }-16 \% \\
\text { spinal cord }\end{array}$ & $90-120 \mathrm{~kg} / \mathrm{ha}$ & \multicolumn{2}{|c|}{} \\
\hline
\end{tabular}

After analyzing the chemical composition of these fertilizers, we see that their main components are sodium, potassium, sulfur and phosphorus

On the test ground plots of the Frunze PSP located near the reservoirs (based on Remote Sensing Data processing results), the depth of the first aquifer water and the direction of underground currents were taken into account (Fig. 3), the angles of the slope were calculated and the corresponding places of water and wind erosion process were discovered after SRTM data analysis results. The analysis of fertilizers uses in these areas (according to a land user priori information) in order to calculate the potential volumes of solid runoff and its chemical composition was made. 
Samples of water in these places also were taken (for further laboratory analysis), the rules of the MPC of chemical substances in the water objects were analyzed.

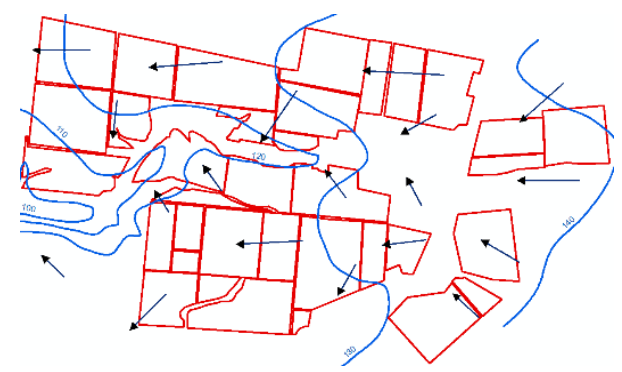

Fig. 3 - Isohyps of the first aquifer waters occurrence

Results of the chemical composition of water samples examination:

1) $\mathrm{BOD}_{5}-4,23 \mathrm{mg} \mathrm{O}_{2} / \mathrm{dm}^{3}$ (exceeded the norm of MPC SanPin $(3,2)$ [2]);

2) $\mathrm{COD}-24,1 \mathrm{mg} \mathrm{O} / \mathrm{dm}^{3}$ (exceeded the norm of MPC SanPin (15) [2]);

3) Ammonium nitrogen $-0.4 \mathrm{mg} / \mathrm{dm}^{3}$;

4) Phosphates $-2.34 \mathrm{mg} / \mathrm{dm}^{3}$;

5) Rigidity - $14,5 \mathrm{mmol} / \mathrm{dm}^{3}$ (exceeded the norm of MPC SanPin (7) [2]);

6) Cesium-137 - 0,048 Bq/dm ${ }^{3}, \mathrm{~kg}$;

7) Nitrates - $132 \mathrm{mg} / \mathrm{dm}^{3}$ (exceeded the norm of MPC SanPin (45) [2]).

Let's consider the most important consequences of the further occurrence of water ecosystems pollution processes. Figure 4 shows the distribution of phosphoruscontaining components in urban sewage before and after biological purification. Polyphosphates are hydrolyzed to orthophosphates, and the bulk of soluble organic phosphorus-containing compounds are converted into orthophosphates as a result of the biological decomposition of organic matter.

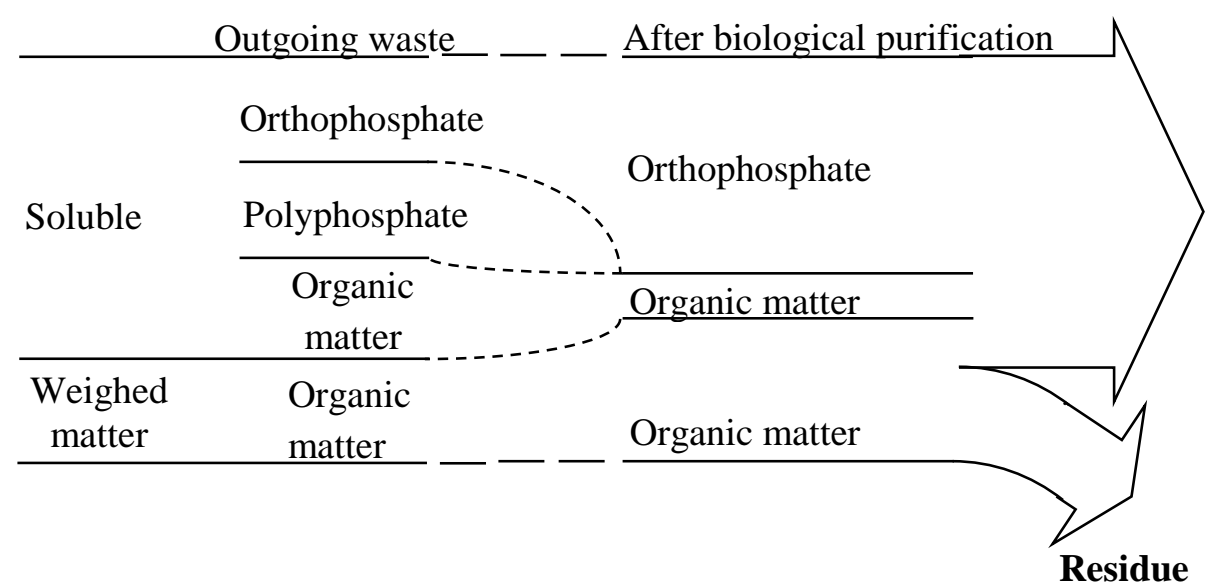

Fig. 4 - Condition of phosphorus-containing components

Usually, weighed phosphorus substances are understood as organic phosphates, but this group may also include chemically precipitated orthophosphates and biologically bound polyphosphates [3]. The composition of phosphates in suspended 
matter is usually not very interesting, because the suspended matter is separated from water by methods, which are selective in relation to not the particles, but their size, charge, density, etc.

Orthophosphates - with two or three exceptions, are the only salts of phosphoric acid, found in nature. They are also the only salts of phosphoric acid currently used in fertilizers.

Polyphosphates are polymers of phosphates, the chain of which passes between other chemical groups. This type of polymerization is known as a condensation reaction. Phosphate bonds are usually high-energy covalent bonds, which means that energy is released by breaking these bonds spontaneously or as a result of enzymatic catalysis.

All phosphate fertilizers by water solubility can be divided into three groups:

1) soluble in water (they are easily digested by any crops);

2) insoluble in water, but soluble in weak acids (including organic acids, available for plants);

3 ) insoluble in water and poorly soluble in weak acids (phosphates which are not digested by the vast majority of cultures, provided that these compounds are not decomposed by acidic soils with the appearance of more easily soluble salts).

Influence of sodium and potassium components of mineral fertilizers on the processes of reservoirs vital activity is approximately the same as for phosphorus components, therefore observation of their incidences is also extremely important.

\section{Conclusions}

Research of chemical indicators for situated around the test sites territories reservoirs has revealed their exceeding the norms of mineral substances MPC. The study of probable ways entering these substances into aquatic ecosystems outlined anthropogenic way of their pollution as a result of agricultural activity on surrounding land parcels. The interaction of mineral agrochemical fertilizers usage with the situation of exceeding the MPC norms in the reservoirs has analyzed.

The performed work proves the necessity of integrated approach applying to regulating the provision of region environmental safety and the need for an appropriate system of analysis and management decision making on environmental management based on geoinformation technologies using remote and contact measurements data.

\section{REFERENCES (TRANSLATED AND TRANSLITERATED)}

1. Guseva, T. V. (Ed.). (2011). Hydro-chemical indicators of the environment state: Reference materials. Moscow: FORUM: INFRA (in Russian).

2. Vinberg, G. G. (1975). Biological self-purification and water quality formation. Moscow (in Russian).

3. Report on the state of the environment in the Kharkiv region in 2015 (Rep.). (2016). Retrieved https://menr.gov.ua/files/docs/XАРКІВСЬКА\%20ОБЛАСТЬ.pdf (in Ukrainian). 4. Henze, M., Armoes, P., La Courne-Jansen, J., \& Arvan, E. (2004). Wastewater treatment. Biological and Chemical Processes (S. V. Kalyuzhny, Ed.; T. P. Mosolovy, Trans.). Moscow: Mir (in Russian). 
О.С. Гребень, О.М. Трофимчук

\section{ОСОБЛИВОСТІ ЕВТРОФІКАЦЇ̈ ВОДОЙМИЩ ЕЛЕМЕНТАМИ} АГРОХІМІЧНИХ ДОБРИВ

Анотація. Фосфор, як і азот та калій, необхідний для нормального розвитку рослин. Джерелом фосфору для рослин $є$ фосфати грунту, головним чином фосфат кальцію $\mathrm{Ca}_{3}\left(\mathrm{PO}_{4}\right)_{2}$. Але для більшості грунтів фосфату кальцію недостатньо. Крім того, через його нерозчинність у воді він практично недоступний для рослин. Тому внесення в грунт розчинних фосфатів, так званих фосфорних добрив, має надзвичайно велике значення для підвищення врожаю сільськогосподарських культур.

У статті проаналізовано хімічний склад аграрних добрив та механізми впливу їх елементів на процеси життєдіяльності водних екосистем. Проаналізовано їх розчинність у воді, а також їх вірогіднісний вплив на розвиток процесів цвітіння та замулювання водоймищ, зниження популяцій видів їх мешканців.

Ключові слова: дистанційне зондування; геоінформаційна система; евтрофікація; сільськогосподарське виробництво; екологія

\section{Гребень Олександр Сергійович}

старший викладач кафедри геоінформаційних технологій та космічного моніторингу Землі Національного аерокосмічного університету імені М.Є. Жуковського «Харківський авіаційний інститут»

Адреса робоча: 61070 Україна, м. Харків, вулиця Чкалова, 17

e-mail: a.greben@khai.edu

\section{Трофимчук Олександр Миколайович}

член-кореспондент Національної академії наук України, доктор технічних наук, професор, директор Інституту телекомунікацій i глобального інформаційного простору НАН України

Адреса робоча: 03186 Україна, м. Київ, Чоколівський бульвар, 13

e-mail: itelua@kv.ukrtel.net

ORCID ID 0000-0003-3782-4209 